\title{
Causes and Effects of Failure to File Annual Returns in Developing Countries Based on the Theory of Planned Behavior and Economic Deterrence Theory
}

\author{
Kelvin Seta ${ }^{1}$, Jackson Phiri² \\ ${ }^{1}$ Graduate School of Business, University of Zambia, Lusaka, Zambia \\ ${ }^{2}$ Department of Computer Sciences, School of Natural Sciences, University of Zambia, Lusaka, Zambia \\ Email: kelvinseta@gmail.com, jackson.phiri@cs.unza.zm
}

How to cite this paper: Seta, K. and Phiri, J. (2019) Causes and Effects of Failure to File Annual Returns in Developing Countries Based on the Theory of Planned Behavior and Economic Deterrence Theory. Open Journal of Business and Management, 7, 1564-1576.

https://doi.org/10.4236/ojbm.2019.74108

Received: July 5, 2019

Accepted: August 4, 2019

Published: August 7, 2019

Copyright $\odot 2019$ by author(s) and Scientific Research Publishing Inc. This work is licensed under the Creative Commons Attribution International License (CC BY 4.0).

http://creativecommons.org/licenses/by/4.0/

\begin{abstract}
Companies are required by the Companies Act No. 10 of 2018 to file annual returns with the Registrar of companies within ninety (90) days following the year end. However, most companies do not comply with this requirement. Therefore, this study is aimed at determining the causes and effects of failure by companies limited by guarantee to file annual returns with Patents and Companies Registration Agency (PACRA). The research study used a case study in a descriptive form to get in-depth and detailed information on the causes and effects of failure to file annual returns with PACRA by companies limited by Guarantee. The study had a total sample size of 151 respondents with 121 from companies limited by guarantee selected within Lusaka district and 30 PACRA employees from the head office in Lusaka. The study was both qualitative and quantitative using primary and secondary data. The primary data were collected using structured questionnaires using a simple random sampling technique. The analysis was done both qualitatively and quantitatively using the statistical package SPSS. The study findings revealed that, failure to file annual returns by companies limited by guarantee was caused by a number of reasons such as: weak or non-existent penalties, complicated filing process, lack of understanding of the companies' post incorporation obligations and limited sensitization on the filing requirements for companies. Based on these results, the study made the following recommendations: PACRA should streamline the filing of annual return process to make it easier for the clients to file. Additionally, the penalties for non-compliance should be more punitive in order to deter any form of non-compliance. There is also a need for PACRA to restructure their sensitization programs to ensure that all their target groups are covered.
\end{abstract}




\section{Keywords}

Annual Return, Limited by Guarantee, Post Incorporation and Filing

\section{Introduction}

Patents and Companies Registration Agency (PACRA) was established to respond to the needs of the business community with the view of creating an efficient agency and merging the mandate of the Registrar previously provided for under multiple legislations [1]. The PACRA Act empowers the Registrar with the authority to oversee the administration of the Companies Act, Registration of Business Names Act, Trade Mark Act, Registered Designs Act and Patents Act.

Before the enactment of the Patents and Companies Registration Act, PACRA was known as the Patents and Companies Registration Office (PACRO) which was a semi-autonomous and self-financing executive agency under the Ministry of Commerce, Trade and Industry (MCTI). PACRO was a department under MCTI until it was hived off from the civil service and was later commercialized under the public service reform programme established by the Treasury Authority No. 4 of 1997 [2]. PACRO was granted administrative autonomy and mandated to continue administering and attending to matters incidental to the Companies Act, Patents Act, Registrations of Business Names Act, Trademarks Act and Registered Designs Act.

Section 270(1) of the companies Act No 10 of 2017, requires companies to lodge an annual return in the prescribed form within ninety days after the end of the financial year. An annual return that is not filed within the period specified in subsection (1), shall attract a penalty as prescribed. There have been a lot of sensitization programs undertaken by PACRA to educate the general public on the need to comply with the Companies Act. However, this has not helped in improving compliance as still a large number of companies do not comply with the post registration obligations. This has resulted in most companies on the database having information that is not up-to-date and loss of revenue for the Government. Hence, this study is being undertaken in order to determine the causes and effects of non-filing of annual returns among companies limited by guarantee in Lusaka. The research also sought to establish strategies that should be implemented by PACRA in order to improve the filing of annual returns by companies.

\section{Literature Review}

[3] conducted a study on the impact of tax payer education on tax compliance in South Africa and this study emphasized the need for education if compliance is to improve among tax payers. [4] conducted a study on the causes and consequences of failure to file annual returns by the tax payer in Shinyanga Municipality and this study revealed that most tax payers had less knowledge on the tax law and this contributed to non-compliance. According to [5] who conducted a 
study on Impact of Tax Knowledge, Tax Compliance Cost, Tax Deterrent, and Tax Measures towards Tax Compliance Behavior in Malaysia, the study revealed that there is a positive relationship between tax knowledge and tax compliance. Tax knowledge included such things as a tax payers understanding tax law and regulations. This equips the tax payer with knowledge in relation to issues of rebate, relief, tax returns and deduction from different taxpayer category of joint assessment, business and self-employed. [6] conducted a study on the analysis of factors affecting tax compliance in the real estate sector. The study revealed that tax knowledge and education has significant positive effect on tax compliance in real estate sector. An increase in tax knowledge by the tax payer can lead to an increase in tax compliance. They also suggested that improved awareness of taxpayers with regards to their tax obligations can be better improved through enhanced tax education services rather than just provide them simple guidelines on filing tax returns. [7] in their study on determinants of tax compliance concluded that tax knowledge of taxpayer can be equipped and enhanced through education. [8] conducted a study on the role of taxation education on taxation knowledge and its effect on tax fairness as well as tax compliance on Handicraft SMEs Sectors in Indonesia. The study revealed the existence of a positive and significant relationship between tax education on tax knowledge and tax compliance. [9] conducted a study on the determinants of tax compliance behavior. The study revealed that there is a very insignificant relationship between tax compliance cost and compliance behavior for the corporate tax payers. Additionally, the study revealed the existence of a significant negative relationship between tax deterrence sanctions and tax non-compliance behavior. Furthermore, [8] in their study on the analysis of factors affecting tax compliance in the real estate sector revealed that tax compliance cost is significantly negatively related to tax compliance behavior. A study on tax compliance, corruption and deterrence by [10] revealed that intentions of taxpayer to comply with tax were higher and intentions to evade tax were lower when the tax authorities and administration were perceived as fair and trustworthy as well as deterrence power was high. Another factor suggests that an individual will comply as long as he or she believes that compliance is the social norm. Conversely, if noncompliance becomes pervasive, then the social norm of compliance disappears. This perspective also suggests that, if government can affect the social norm of compliance, then such government policies represent another, potentially significant tool in government's battle with tax evaders. A study by [11] on a model for improving E-Tax systems adoption in rural Zambia based on the Technology Assessment Model (TAM) revealed the need for more awareness and tax education to the tax payers in order for E-Tax system use to improve. This applies to filing of company returns as well.

\subsection{Source of the Model of This Research}

The research looked a lot of theories and models done by other researchers in line with the research topic in order to have an in-depth understanding and be able 
to develop a model that will address the research problem. The following theories were reviewed; economic deterrence theory and the theory of planned behavior.

\subsubsection{Economic Deterrence Theory}

Economic Deterrence theory is a theory under criminology and was developed by Becker [12]. This theory is based on the concept that, if the consequence of committing a crime outweighs the benefit of the crime itself, the individual will be deterred from committing the crime. This is founded in the idea that all individuals are aware of the difference between rights and wrong and the consequences associated with wrong or criminal behaviors. Proponents of deterrence theory believe that people choose to obey or violate the law after calculating the gains and consequences of their actions. In relation to the problem of failure to file annual returns with the companies' registry by companies in Zambia, it can be assumed that the consequence of not filing annual returns does not outweigh the benefit of fulfilling the obligation. The deterrence model of regulatory compliance states that the certainty and severity of sanctions are the key determinants of compliance. Under the repealed Companies Cap 388 the Registrar of companies had no powers to administratively impose sanction. All matters were to be referred to the High Court with the approval of the Director of Public Prosecutions (DPP). The Companies Act No 10 of 2017 provides for General Penalties under section 373 administered by the High Court. This could be a fine not exceeding 3, 333 penalty unit (a penalty unit is equivalent to K0.03 or USD $\$ 0.0023$ ) or imprisonment for a term not exceeding 4 years. Further Section 370 also provides for the administrative penalty to be administered by Registrar for any failure to comply with the Act. However, these penalties are too low to enable companies to fully comply with the law. The fee for late filing of annual return is K100 (USD \$7.5) per annum. This amount is too low to force a non-complying company to start filing its company returns.

\subsubsection{Theory of Planned Behaviour}

This is a psychological theory that links beliefs and behavior, tries to explain human behavior. The concept was proposed by Icek Ajzen [13] to improve on the predictive power of the theory of reasoned action by including perceived behavioral control. The TPB is a general model to predict behavior which states that, "Intention is an indication of a person's readiness to execute a given behavior, and it is considered to be the immediate forebear of behavior. The intention is based on attitude toward the behavior, subjective norm, and perceived behavioral control, with each predictor weighted for its importance in relation to the behavior and population of interest" [13]. In the case of Filing annual returns, the model states that compliance is influenced by intention to comply, which is predicted by the following interrelated variables: perceived behavioral control (i.e., ease or difficulty of performing the behavior-in our case filing annual returns), subjective norms (i.e., perceived social/peer pressure from PACRA or Government), and attitude (i.e., positive or negative evaluation of Compliance). According to this theory, the behavior of individuals within the 
society is under the influence of definite factors which originate from certain reasons and emerge in a planned way. The ability to perform a particular behavior depends on the fact that the individual has a purpose towards that behavior (behavioral intention). Behavioral intention in turn depends on three factors that is Attitude towards the behavior, subjective norms and perceived behavioral control [13] (Figure 1).

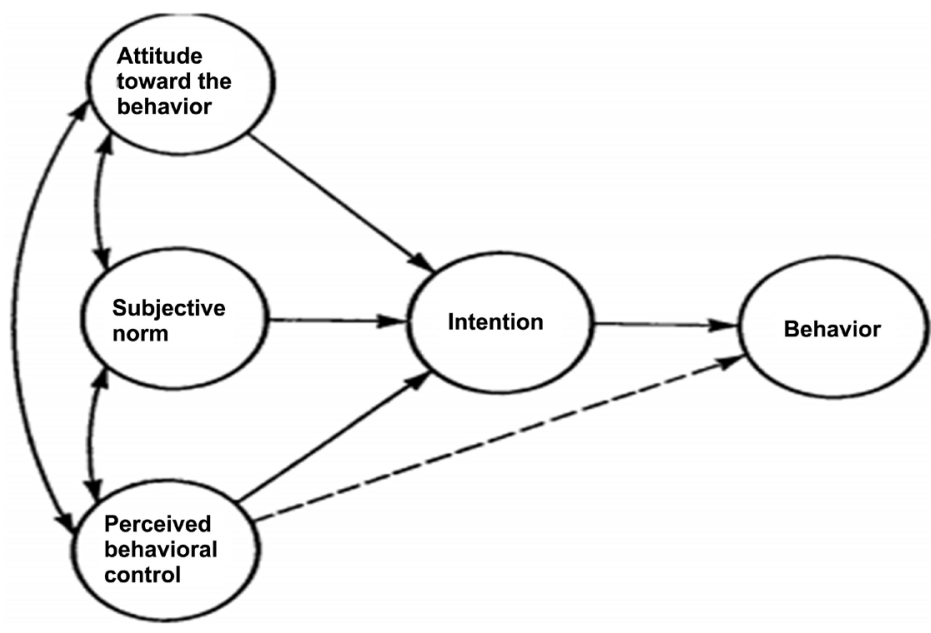

Figure 1. Theory of planned behavior. Source: Ajzen, 1991, p. 182. (2019).

In relation to annual returns compliance, it is clear that there are multiple factors that lead companies to behave in the manner that they do with regards to filing of annual returns despites being knowledgeable of some of the penalties that are accompanied by lack of fulfilling that obligation. This theory gives an insight on how personal factors could influence the filing of company returns by companies.

\subsubsection{Proposed Hypotheses}

H1: Companies without an understanding of annual returns are more likely to be non-compliant.

H2: Companies that lack awareness of effects non-compliance and penalties are more likely to be non-compliant.

H3: Companies that have been sensitized about annual returns are more likely to be compliant.

\section{Methodology}

The research study used a case study in descriptive form to get in-depth and detailed information on the causes and effects of failure to file annual returns with PACRA by companies limited by Guarantee. The aforementioned form helped the research to present the data and information from the respondents the way that would represent the true reflection of the actual picture on the ground. The research focused much on getting facts and interpreting the opinions of the general public in relation to the causes and effects of failure to file annual returns 
with PACRA by companies limited by Guarantee The researcher considered the responses of the participants of the study so as to try and understand why a lot of companies fail to file annual returns.

Primary data was collected with the aid of questionnaires with structured questions. Questions that were used in the research included closed and open-ended questions. Secondary data is information or data already collected by other researchers or institutions, usually for different purposes [14]. The secondary sources of data emanated from both published and unpublished articles, magazines, journals and publications from prominent international bodies and organizations on the subject of compliance with filing company returns.

Population of a study refers to a complete set of individuals or subjects, objects or events having common observable characteristics in which the researcher is interested [15]. The target population for the study was comprised of both public and private sector. Target population is the aggregate of entire set of study units that have a potential for providing the relevant data for the research study to make inferences [16]. The Patents and Companies Registration Agency (PACRA) statistics indicated that there are approximately 475 companies Limited by Guarantee in Lusaka District. The study had a sample size of 150 respondents comprising of 120 representatives from the companies and $30 \mathrm{em}$ ployees from PACRA. Only 121 respondents participated in the study by responding to the questionnaires.

The Statistical Product and Service Solutions-SPSS version 20.0, an IBM product since 2009 [17] was used to analyze the data. The specific statistical method that was used was descriptive statistics from SPSS version 20. Therefore, the response rate was $80.7 \%$.

Figure 2 explains some of the factors that PACRA should take into account when addressing the problem of failure to file annual returns. The aim of this framework is to establish the relationship between the independent variables and the dependent variable. It is important to test if the independent variables have an effect on the dependent variable and determine the impact on the dependent variable.

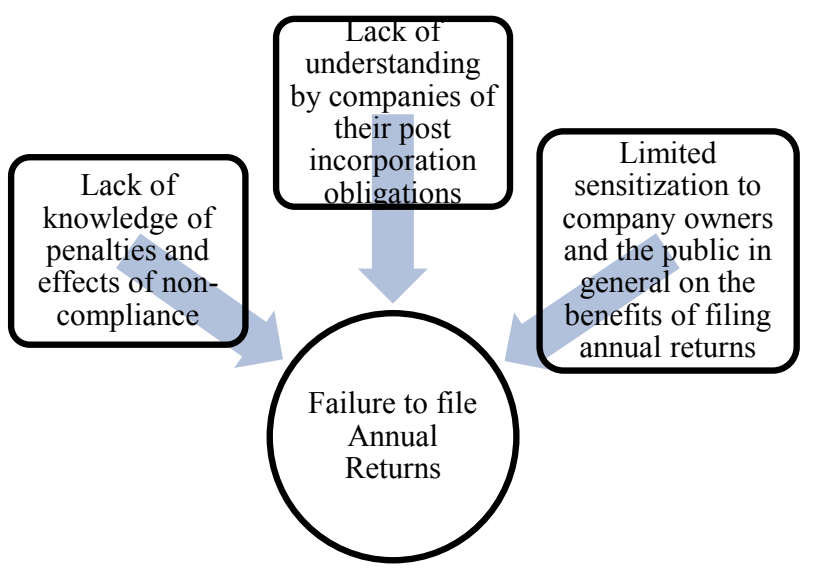

Figure 2. Possible causes of failure to file company returns. Source, Author (2019). 


\section{Findings and Discussions}

\section{Gender Distribution}

Results show that $48 \%$ (58 out of 121) of the respondents were Female while $52 \%$ (63 out of 121) were Male. Additionally, $40 \%$ (48 out of 121) of the respondents were Married, 9\% (11 out of 121) of the respondents were Divorced, 4\% (5 out of 121) of the respondents were Widowed and 47\% (57 out of 121) were Single.

\section{Understanding of Annual Returns}

Moreover, results also show that 90\% (109 out of 121) of the respondents agreed to having an understanding of what annual returns were while only $10 \%$ (12 out of 121) did not have an understanding of what annual returns were.

\section{Knowledge of Existence of Penalties}

Other results also show that $85 \%$ (103 out of 121) of the respondents acknowledges the existence of penalties as a result of failure to file annual returns while only $15 \%$ (18 out of 121 ) disputed by saying there are no penalties enforced by PACRA for failure to file returns.

Table 1 shows the various responses the respondents gave as the causes of failure to file annual returns by companies limited by guarantee. From the table above, complicated filing procedure is the most agreed on cause amongst the respondents with the biggest share of the proportion of $93(\sim 77 \%)$.

Table 1. Causes of failure to file annual returns.

\begin{tabular}{cccc}
\hline & YES (\%) & NO (\%) & Total \\
\hline Limited sensitization on annual returns & $75(62)$ & $46(38)$ & 121 \\
Lack of filing requirement knowledge & $70(57.9)$ & $51(42.1)$ & 121 \\
Lack of knowledge of the penalties & $39(32.2)$ & $82(67.8)$ & 121 \\
Weak penalties & $80(66.1)$ & $41(33.9)$ & 121 \\
Complicated filing procedure & $93(76.9)$ & $28(23.1)$ & 121 \\
\hline
\end{tabular}

Figure 3 above shows that $48 \%$ (58 out of 121) of the respondents indicated that they have been sensitized while 52\% (63 out of 121) have not been sensitized on annual returns filing.

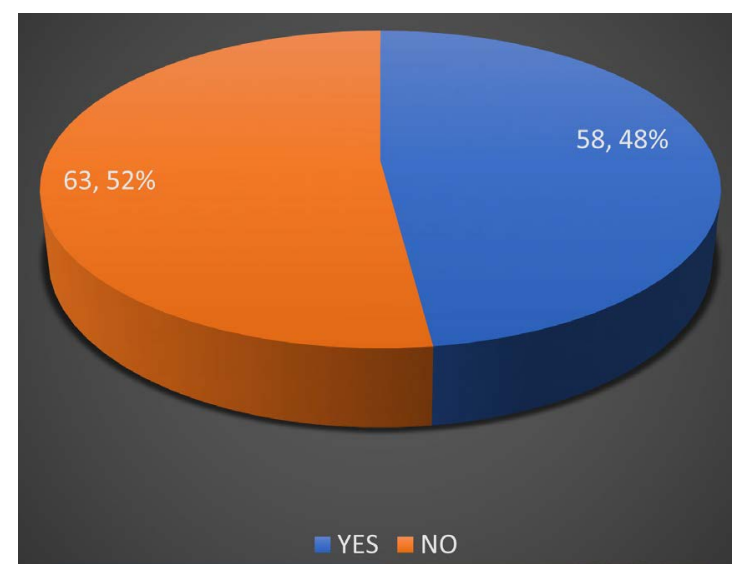

Figure 3. Sensitization by PACRA. 


\subsection{Statistical Significance (P-Values)}

The P-value was used to test the hypotheses by cross tabulation of certain questions: -

$\mathrm{P}$-value $=\mathrm{P}>0.05$ (by statistical convention, 0.05 probability level was used as a critical value);

Degrees of freedom $(\mathrm{df})=\mathrm{N}-1$ (where $\mathrm{N}$ is the total number of Participants/Respondents);

Pearson Chi-Square values $=$ were shown as asymptotic value in the table after the cross tabulation of the questions had been done.

If the calculated chi-square value was less than the 0.05 , the hypothesis would be accepted.

If the value is greater than the value of 0.05 , the hypothesis would be rejected.

\subsection{Hypotheses Testing}

Hypothesis 1: Companies without an understanding of annual returns are more likely to be non-compliant.

Table 2 seeks to test the hypothesis that Companies without an understanding of annual returns are more likely to be non-compliant. Out of a total of 121 respondents 109 indicated that they had an understanding of what annual returns were and out of which 52 were not compliant with the requirement to file annual returns with PACRA and 57 indicated that they were compliant. Furthermore, the table indicates that out of the 12 respondents that did not have an understanding of what annual return were, 8 of them were compliant and only 4 were not compliant with requirement to file annual returns Companies Registry.

Table 2. Are you as an institution compliant with PACRA? ${ }^{\star}$ Do you understand what annual returns are?

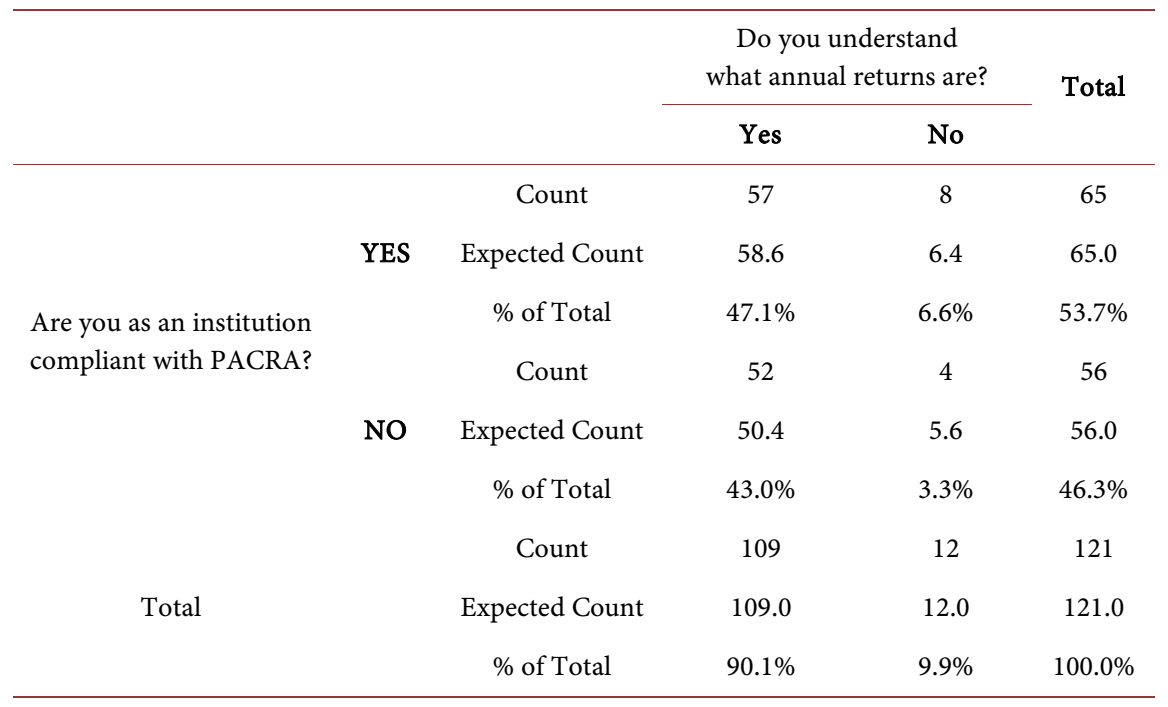

Table 3 shows that there is no statistically significant relationship between understanding annual returns and filing annual returns. Therefore, the research 
hypothesis "Companies without an understanding of annual returns are more likely to be non-compliant" is rejected. The decision to reject the hypothesis is supported by the asymptotic significance value of 0.343 in Table 3 which is greater than the probability value (P-Value) of 0.05 indicating that research hypothesis should be rejected.

Table 3. Chi-square tests.

\begin{tabular}{|c|c|c|c|c|c|}
\hline & Value & $\mathrm{df}$ & $\begin{array}{l}\text { Asymp. Sig. } \\
\text { (2-sided) }\end{array}$ & $\begin{array}{l}\text { Exact Sig. } \\
\text { (2 sided) }\end{array}$ & $\begin{array}{l}\text { Exact Sig } \\
\text { (1 sided) }\end{array}$ \\
\hline Pearson Chi-Square & $0.898^{\mathrm{a}}$ & 1 & 0.343 & \multirow{6}{*}{0.380} & \multirow{6}{*}{0.262} \\
\hline Continuity Correction $^{\mathrm{b}}$ & 0.413 & 1 & 0.520 & & \\
\hline Likelihood Ratio & 0.919 & 1 & 0.338 & & \\
\hline Fisher's Exact Test & & & & & \\
\hline Linear-by-Linear Association & 0.891 & 1 & 0.345 & & \\
\hline $\mathrm{N}$ of Valid Cases ${ }^{\mathrm{b}}$ & 121 & & & & \\
\hline
\end{tabular}

${ }^{\mathrm{a}} 0$ cells $(0.0 \%)$ have expected count less than 5 . The minimum expected count is $5.55 .{ }^{\mathrm{b}}$ Computed only for a $2 \times 2$ table.

Hypothesis 2: Companies that lack awareness of the effects of non-compliance and penalties are more likely to be non-compliant.

Table 4 seeks to test the hypothesis that companies that lack awareness of non-compliance effects and penalties are more likely to be non-compliant. Out of a total of 121 respondents 103 indicated that they were aware of effects and penalties for non-compliance and out of which 45 were not compliant with PACRA and 58 indicated that they were compliant. Furthermore, the table indicates that out of the 18 respondents that were not aware of effects and penalties, 11 of them were compliant and only 7 were not compliant with PACRA.

Table 4. Are you as an institution compliant with PACRA? ${ }^{\star}$ Are you aware of any effects/penalties that arise as a result of being non-compliant with filing annual returns?

\begin{tabular}{|c|c|c|c|c|c|}
\hline & & & \multicolumn{2}{|c|}{$\begin{array}{l}\text { Are you aware of any effects that arise as a } \\
\text { result of non-compliant with PACRA? }\end{array}$} & \multirow[t]{2}{*}{ Total } \\
\hline & & & Yes & No & \\
\hline \multirow{6}{*}{$\begin{array}{l}\text { Are you as an } \\
\text { institution } \\
\text { compliant with } \\
\text { PACRA? }\end{array}$} & & Count & 58 & 7 & 65 \\
\hline & YES & Expected Count & 55.3 & 9.7 & 65.0 \\
\hline & & $\%$ of Total & $47.9 \%$ & $5.8 \%$ & $53.7 \%$ \\
\hline & & Count & 45 & 11 & 56 \\
\hline & NO & Expected Count & 47.7 & 8.3 & 56.0 \\
\hline & & $\%$ of Total & $37.2 \%$ & $9.1 \%$ & $46.3 \%$ \\
\hline \multirow{3}{*}{ Total } & & Count & 103 & 18 & 121 \\
\hline & & Expected Count & 103.0 & 18.0 & 121.0 \\
\hline & & $\%$ of Total & $85.1 \%$ & $14.9 \%$ & $100.0 \%$ \\
\hline
\end{tabular}


Table 5 shows that there is no statistically significant relationship between awareness of penalties and effects of non-compliance and filing of annual returns. Therefore, research hypothesis "Companies that lack awareness of non-compliance effects and penalties are more likely to be non-compliant" is rejected. The decision to reject the hypothesis is supported by the asymptotic significance value of 0.171 in Table 5 which is greater than the probability value (P-Value) of 0.05 indicating that research hypothesis should be rejected.

Table 5. Chi-square tests.

\begin{tabular}{|c|c|c|c|c|c|}
\hline & Value & $\mathrm{df}$ & $\begin{array}{l}\text { Asymp. Sig. } \\
\text { (2-sided) }\end{array}$ & $\begin{array}{l}\text { Exact Sig. } \\
\text { (2 sided) }\end{array}$ & $\begin{array}{l}\text { Exact } \text { Sig. } \\
\text { (1 sided) }\end{array}$ \\
\hline Pearson Chi-Square & $1.871^{\mathrm{a}}$ & 1 & 0.171 & \multirow{6}{*}{0.205} & \multirow{6}{*}{0.133} \\
\hline Continuity Correction ${ }^{\mathrm{b}}$ & 1.235 & 1 & 0.266 & & \\
\hline Likelihood Ratio & 1.871 & 1 & 0.171 & & \\
\hline Fisher's Exact Test & & & & & \\
\hline Linear-by-Linear Association & 1.855 & 1 & 0.173 & & \\
\hline $\mathrm{N}$ of Valid Cases ${ }^{\mathrm{b}}$ & 121 & & & & \\
\hline
\end{tabular}

${ }^{\mathrm{a}} 0$ cells $(0.0 \%)$ have expected count less than 5 . The minimum expected count is $8.33 .{ }^{\mathrm{b}}$ Computed only for a $2 \times 2$ table.

Hypothesis 3: Companies that have been sensitized about annual returns are more likely to be compliant.

Table 6 seeks to test the hypothesis that Companies that have been sensitized about annual returns are more likely to be compliant. Out of a total of 121 respondents 58 indicated that they have been sensitized and out of which 26 were not compliant with PACRA and 32 indicated that they were compliant. Furthermore, the table indicates that out of the 63 respondents that have never been sensitized, 33 of them were compliant and 30 were not compliant.

Table 6. Are you as an institution compliant with PACRA? ${ }^{*}$ Have you ever been sensitized by PACRA?

\begin{tabular}{|c|c|c|c|c|c|}
\hline & & & \multicolumn{2}{|c|}{$\begin{array}{l}\text { Have you ever been } \\
\text { sensitized by PACRA? }\end{array}$} & \multirow{2}{*}{ Total } \\
\hline & & & YES & NO & \\
\hline \multirow{7}{*}{$\begin{array}{l}\text { Are you as an institution } \\
\text { compliant with PACRA? }\end{array}$} & & Count & 32 & 33 & 65 \\
\hline & YES & Expected Count & 31.2 & 33.8 & 65.0 \\
\hline & & $\%$ of Total & $26.4 \%$ & $27.3 \%$ & $53.7 \%$ \\
\hline & & Count & 26 & 30 & 56 \\
\hline & NO & Expected Count & 26.8 & 29.2 & 56.0 \\
\hline & & $\%$ of Total & $21.5 \%$ & $24.8 \%$ & $46.3 \%$ \\
\hline & & Count & 58 & 63 & 121 \\
\hline \multirow[t]{2}{*}{ Total } & & Expected Count & 58.0 & 63.0 & 121.0 \\
\hline & & $\%$ of Total & $47.9 \%$ & $52.1 \%$ & $100.0 \%$ \\
\hline
\end{tabular}


Table 7 shows that there is no statistically significant relationship between being sensitized about annual returns and being compliant. Therefore, research hypothesis that "Companies that have been sensitized about annual returns are more likely to be compliant" is rejected. The decision to reject the hypothesis is supported by the asymptotic significance value of 0.758 in Table 7 which is greater than the probability value (P-Value) of 0.05 indicating that research hypothesis should be rejected.

Table 7. Chi-square tests.

\begin{tabular}{|c|c|c|c|c|c|}
\hline & Value & df & $\begin{array}{c}\text { Asymp. Sig. } \\
\text { (2-sided) }\end{array}$ & $\begin{array}{l}\text { Exact Sig. } \\
\text { (2 sided) }\end{array}$ & $\begin{array}{l}\text { Exact Sig. } \\
\text { (1 } \text { sided) }\end{array}$ \\
\hline Pearson Chi-Square & $0.095^{\mathrm{a}}$ & 1 & 0.758 & \multirow{6}{*}{0.856} & \multirow{6}{*}{0.450} \\
\hline Continuity Correction $^{\mathrm{b}}$ & 0.016 & 1 & 0.900 & & \\
\hline Likelihood Ratio & 0.095 & 1 & 0.758 & & \\
\hline Fisher's Exact Test & & & & & \\
\hline Linear-by-Linear Association & 0.094 & 1 & 0.759 & & \\
\hline $\mathrm{N}$ of Valid Cases ${ }^{\mathrm{b}}$ & 121 & & & & \\
\hline
\end{tabular}

${ }^{\mathrm{a}} 0$ cells $(0.0 \%)$ have expected count less than 5 . The minimum expected count is $26.84 .{ }^{\mathrm{b}} \mathrm{Computed}$ only for a $2 \times 2$ table.

\subsection{Summary}

The analysis of the data revealed that the majority of the respondents had an understanding of what annual returns were despite the low filling levels. However, this understanding did not translate into full compliance with filing company annual returns. The study also showed that there was some existence of knowledge gaps in understanding post incorporation requirements for companies by PACRA employees and this in a way has contributed to non-compliance. Additionally, the study revealed that the complicated filing process was one of the major cause of non-compliance. Finally, from the findings it was concluded that the research hypothesizes were not true and were all rejected.

\section{Conclusion}

Looking at the three objectives of this study, it can be concluded that the demand for many people wanting to register companies with the company registry is being met adequately. However, the levels of understanding of what their post registration obligations being exhibited are quite alarming. The majority of the respondents seem not to know what annual returns are and when they should be filed and with whom they should be filed. This in itself is a major contributing factor to the low compliance levels as clearly you cannot file what you don't know. The situation is even more alarming as the study further reviewed that there was also knowledge gap existing in terms of annual returns among the PACRA staff who are supposed to be the ones sensitizing the public about the annual return filing. Hence there is a need for PACRA to address this issue as 
soon as possible in order to avoid the misinformation about what returns are all about.

\section{Recommendations}

From the study above it can be deduced that a lot of work needs to be done if companies and businesses are to fully comply with the filing of returns. The need for continued sensitization of the members of the public cannot be overemphasized. However, the sensitization should be more focused towards the target groups, if it is to be more meaningful as opposed to using the traditional methods of radio and television which have not yielded the intended results. PACRA should also continue to sensitize their employees about the post registration obligation and the companies Act in general in order to bridge the knowledge gap problem. Companies and businesses should be sensitized about the post registration obligation at the point of registration as well. Additionally, the penalties for non-compliance should be more punitive in order to deter would-be offenders. Furthermore, PACRA needs to streamline the registration processes by reducing the number of forms to be filed and also introduce a paperless registration of the businesses and companies.

There is need to amend the Act to ensure that businesses and companies that do not file annual returns after a specified period of time say 2 years should be deemed to be non-operational and the Registrar should deregister such businesses and companies. The Registrar of companies needs to be given powers to prosecute companies that operate without having been registered with PACRA. These informal businesses and companies are also creating a problem as a person with a registered business or company will not be motivated to comply with the requirements of the Companies Act if some businesses and companies are left to operate without going through the formal registration process. Registration of a business or company raises the cost of doing business for a registered business or company. Additionally, unregistered businesses and companies give rise to unfair competitive advantage to the business or company which is registered.

\section{Acknowledgments}

The authors wish to acknowledge all those who took part in the study.

\section{Conflicts of Interest}

The authors declare no conflicts of interest regarding the publication of this paper.

\section{References}

[1] Patents and Companies Registration Agency. Annual Report 2013.

[2] Zambia National Parliamentary Debate 2009.

http://www.parliament.gov.zm/node/1665 
[3] Roshelle, M. (2004) The Impact of Taxpayer Education on Tax Compliance in South Africa.

[4] Samwel, F. (2013) Causes and Consequences of Failure to File the Annual Return by the Tax Payer: A Case Study of Shinyanga Municipality in Tanzania.

[5] Mira Susanti, B. (2007) Tax Knowledge, Tax Ethics and Tax Non Compliant Behavior of Non-Accounting Postgraduates from Universiti Teknologi MARA (UiTM).

[6] Muoki, N.P. and Rawlings, P.O. (2014) Analysis of Factors Affecting Tax Compliance in Real Estate Sector: A Case of Real Estate Owners in Nakuru Town, Kenya. Research Journal of Finance and Accounting, 5, 4-6.

[7] Alabede, J., Zainol Ariffin, Z. and Idris, K. (2011) Determinants of Tax Compliance Behavior: A Proposed Model for Nigeria. International Research Journal of Finance and Economics, 78, 121-136.

[8] Mukhlis, I., Utomo, S. and Soesetio, Y. (2015) The Role of Taxation Education on Taxation Knowledge and Its Effect on Tax Fairness as well as Tax Compliance on Handicraft SMEs Sectors in Indonesia. International Journal of Financial Research, 6, 167-168. https://doi.org/10.5430/ijfr.v6n4p161

[9] Sapiei, N.S., Kasipillai, J. and Eze, U.C. (2014) Determinants of Tax Compliance Behavior of Corporate Taxpayers in Malaysia. E-Journal of Tax Research, 12, 383-409.

[10] Wilks, D. and Pacheco, L. (2014) Tax Compliance, Corruption and Deterrence: An Application of the Slippery Slope Model. In: Teixeira, A., Ed., Interdisciplinary Insights on Fraud, Chapter 4, Cambridge Scholars Publishing, Cambridge, 87-104.

[11] Soneka, P.N. and Phiri, J. (2019) A Model for Improving E-Tax Systems Adoption in Rural Zambia Based on the TAM Model. Open Journal of Business and Management, 7, 908-918. https://doi.org/10.4236/ojbm.2019.72062

[12] Becker, G.S. (1968) Crime and Punishment-An Economic Approach. The Journal of Political Economy, 76, 169-217. https://doi.org/10.1086/259394

[13] Ajzen, I. (1991) The Theory of Planned Behavior. Organizational Behavior and Human Decision Processes, 50, 179-211. https://doi.org/10.1016/0749-5978(91)90020-T

[14] Blumberg, B., Cooper, D.R. and Schindler, S.P. (2008) Business Research Methods. 2nd Europeans Edition, McGraw-Hill Higher Education, London.

[15] Polit, D.F. and Hungler, B.P. (1999) Nursing Research; Principles and Methods. 6th Edition, Lippincott Williams \& Wilkins, Philadelphia.

[16] Mugenda, O.M. and Mugenda, A.G. (2009) Research Methods: Quantitative and Qualitative Approaches. Acts Press, Nairobi.

[17] Hejase, A. and Hejase, H. (2013) Research Methods: A Practical Approach for Business Students. 2nd Edition, Masadir Inc., Philadelphia. 